\title{
ZOONYMS: CONTEXTUAL MEANING IN LITERARY CONTEXT (BASED ON THE NOVEL “BLESS ME, ULTIMA!” BY RUDOLFO ANAYA)
}

\author{
ЗООНІМИ: КОНТЕКСТУАЛЬНЕ ЗНАЧЕННЯ В ХУДОЖНЬОМУ КОНТЕКСТІ \\ (НА МАТЕРІАЛІ РОМАНУ РУДОЛЬФО АНАЙЇ «БЛАГОСЛОВИ МЕНЕ, УЛЬТІМА!»)
}

\author{
Mintsys E.Ye., \\ orcid.org/ 0000-0002-1891-4658 \\ Senior Lecturer of English Philology Department \\ Vasyl Stefanyk Precarpathian National University
}

\author{
Mintsys Yu.B., \\ orcid.org/ 0000-0003-2150-4008 \\ PhD, Associate Professor of English Philology Department \\ Vasyl Stefanyk Precarpathian National University
}

The present research deals with defining contextual meaning of zoonyms and is based on the novel "Bless me, Ultima" (1972) by Rudolfo Anaya, a famous representative of Chicano literature. It also presents a survey of studies done by Ukrainian and foreign scholars related to animal names, which have been analyzed from different perspectives. Literary context is a fertile ground for animal names, which contribute a lot to its ethnical, philosophic and symbolic peculiarities. It provides clear evidence that animals serve as the source domain for talking about human beings by ascribing to them positive and negative qualities. Zoonyms are a rich source of metaphors, phraseological units, which represent model national cultural views. They reflect man's lasting observation of animals' appearance and behavior, render people's attitude to them, emphasize some of their qualities, turn into symbols, become the cultural and informational fund of every language and create the mindset of every nation. Animal names are an attractive field of study in many regards as they perform various functions, among which rendering human traits of character is the most outstanding. All the zoonyms in the novel compris domestic and wild animals and birds, insects and reptiles, which are typical of the Mexican habitat described in the novel. They possess both positive and negative contextual meanings and are used to express various feelings (disapproval and despair, contempt and empathy, etc.). The zoonym animal, a general concept embracing all the representatives of fauna, holds a special place in the novel. On the one hand, it has a pejorative meaning signifying negative traits of character, on the other hand, it supports the juxtaposition man - animal. It is an open secret that the issue of the contextual meaning of zoonyms is of considerable linguistic interest.

Key words: zoonym, animal name, fauna, context, symbol, stereotype, imagery, simile, connotation, worldview.

Запропонована стаття присвячена визначенню контекстуального значення зоонімів у художньому тексті. Матеріалом дослідження слугує роман «Благослови мене, Ультіма» Рудольфо Анайї, відомого представника літератури чикано. У статті узагальнено результати досліджень представників сучасної науки, які у своїх наукових доробках розглядали різні аспекти анімалізмів. Літературний контекст є родючим ґрунтом для використання зоонімів, які характеризують його етнічні, фрілософські та символічні особливості. Зооніми є багатим джерелом метафор, порівнянь та фрразеологізмів, які віддзеркалюють національно-образну картину світу, особливості культури народу. Назви тварин $€$ цікавою галуззю дослідження, оскільки вони виконують різноманітні функції у контексті, одна із найбільш значущих серед них - зображення рис характеру людини. Усі зооніми в романі поділяються на назви свійських та диких тварин і птахів, комах та рептилій, які є характерними для мексиканського природного середовища, зображеного у літературному творі. Вони набувають позитивного та негативного контекстуального значення, передають цілий спектр почуттів (несхвалення і розпач, презирство та емпатія тощо). Зоонім animal, який є загальним поняттям для позначення всіх представників фауни, посідає особливе місце у романі. 3 одного боку, він має пейоративний відтінок і використовується для позначення негативних характеристик, з іншого - вживається для протиставлення «людина» - «тварина». Вивчення зоонімів має велике значення для збагачення лексичного запасу, кращого розуміння культури країни, сприяє міжкультурній комунікації та відтворенню культурної, національної та мовної картин світу.

Ключові слова: зоонім, назва тварини, фауна, контекст, символ, стереотип, образність, стилістичне порівняння, конотація, картина світу.

Introduction. The term "zoonym" can be defined as a concept embracing all the fauna-related vocabulary. Zoonyms constitute an ancient layer of any language and are a significant component of the vocabulary, and in all languages, their lexical meaning comprises connotative properties, which give rise to metaphoric nomination and testify to the uniqueness of every nation's mindset.
Zoonyms are a rich source of metaphors, phraseological units, symbols, plots, which represent model national cultural views. They reflect man's lasting observation of animals' appearance and behavior, render people's attitude to our "minor brethren", emphasize some of their qualities, turn into symbols, become the cultural and informational fund of every language and create the mindset of every nation. Animal names 
are an attractive field of study in many regards as they perform various functions, among which rendering human traits of character is the most outstanding.

Literary context is a fertile ground for animal names. For example, multiple animalistic images can be found in the works written by the American author of Mexican origin (known as Chicano) Rudolfo Anaya, one of the founders of Chicano literature. His creative activity is in the focus of linguists, philosophers and other scholars interested in the development of cultural historical values of Mexican Americans and in their further influence on the development of the main features of Chicano literature. The publication of R. Anaya's first novel "Bless me, Ultima" in 1972 [14] became a unique event in the development of Mexican American literature. It is a story about a sixyear-old boy Tony who lived in New Mexico whose character developed under the influence of Ultima (a curandera, a healer), the pagan and folklore traditions and his natural environment in whose description zoonyms play a significant role. Of great importance in the writer's work is the imagery which is a tool helping to highlight the evolution of people's spiritual growth and interpret universal issues [11, p. 88].

There is an increasing number of studies done by Ukrainian and foreign scholars related to animal names, which have been analyzed from different perspectives. Among them there are those which view zoonyms as constituents of phraseological units in English (Z.R. Dubravska [4], O.I. Panchenko [7]), Turkish (I.L. Pokrovska [10]), Latin (M.Y. Petryshyn [9]), German and Ukrainian (O.V. Kovalenko [6]), Russian and Hindi (Uma Parihar [21]), Serbian (Sabina Halupka-Res`etar, Biljana Radic [17]), Bengali (Niladri Sekhar Dash, Arpita Ray [15]), etc. M.V. Berezhna [1] considers zoonyms from the point of view of translation, A.V. Golovnia [3], S.V. Talko [12], A.V. Shevchyk [13] define their stylistic peculiarities.

The issue of context and contextual meaning has been widely discussed in numerous linguistic researches by L.V. Shcherba, O. Jespersen, V.V. Vinogradov, R.A. Budagov, R. Jacobson [2], I. Ketchkesh [5], O.O. Kulchytska [18], N.O. Pereverzeva [8] and others. They all support the idea that in finding a new, extraordinary meaning context plays a very important role. "A word when used in a piece of text, usually denotes only one meaning out of multiple meanings it inherently carries. $<\ldots>$ It is the context that determines which meaning of the word should be considered" [15].

The aim of the present article is to define the contextual meaning of zoonyms and their functions in literary context.

\section{Findings and discussion.}

Since ancient times the life of every nation has been closely connected with animals, which were believed to be a kind of totem protecting people and possessing positive and negative qualities. Anna Vinzel stresses the evidence of the interrelation between the animal world and the world of human characters [16]. It has been observed that animal names are quite frequently used to address or refer to human beings in different sociocultural situations in order to dehumanize or elevate an addressee's status [15].

The zoonym "animal" is a collective name to denote all representatives of fauna and to highlight various aspects of their conduct. In the novel by Rudolfo Anaya this zoonym occurs 15 times. As a rule, it has a pejorative shade of meaning because it is common truth that if a man is called an "animal", it is implied that their behavior is disgusting and unacceptable in the society.

For example, one of the characters of the novel Lupito committed a crime. The others consider that he who bears the name "man" cannot kill another human being. It is done only by an animal, that is not aware of the horror of its action, and it should be exterminated: "He is an animal! He has to be shot!" [14, p. 19]; "Tonight a mad animal crawled behind him and took his life. You call that reason! That animal has to be destroyed!" [14, p. 19]. In the above-mentioned examples, the zoonym denotes a cruel, berserk person who is deprived of humaneness and deserves punishment.

In the following example where Lupito is compared to a wild animal, emphasis is laid on the behavior of a trapped person who is dangerous and in despair and is ready for an extreme action. Here, the zoonym partially loses its pejorative connotation. So, on the one hand, we can trace the juxtaposition "animal" - "man", on the other hand it draws a line of similarity between two species: man and animal [15] and leaves no doubt about the animal-like nature of people [16, p. 231]: "The man they hunted had slipped away from human understanding; he had become a wild animal, and they were afraid" [14, p. 19]; "As long as I live I will never forget those wild eyes, like the eyes of a trapped, savage animal" [14, p. 18]; "Let us act like men! That is not an animal down there, that is the man. Lupito!' [14, p. 20].

In the description of various human behavioral aspects, the zoonym in question is totally deprived of negative connotation. On the contrary, it is used to arouse sympathy and empathy for the characters who feel miserable and unhappy. For example, Uncle Lucas' look after a long fever resembled that of an animal: "His dark eyes looked at us like 
a captured animal' [14, p. 97]. In order to show the detrimental effect of war on the human life, the author compares Leon's voice with that of an animal: "Sometimes at night he howled and cried like a wild animal" $[14$, p. 65]. The following examples demonstrate an overwhelming hunger experienced by the characters: "He ate like starved animal" [14, p. 03]; "Leon and Gene ate everything set before them like starved animals" [14, p. 181]. The author also tries to explain how helpless, ignorant and incapable of seeing the truth people sometimes are: "Men walk the world as animals and we must pray that they see God's light" [14, p. 30]; "Then we would be like the dumb animals of the fields" [14, p. 197]. The peak of despair taking possession of the father who is on the verge of losing his child is reflected in the following example: “'My daughter is dying, 'he moaned, and the wind snapped at his pitiful, animal cry" [14, p. 188].

It should be mentioned that in most cases the zoonym animal is found in the pattern of a simile, and it is modified by such attributes as wild, captured, savage, huge, turgid, frightened, starved, etc. in order to specify some idea, add various shades to it and produce a stronger emotional stylistic effect.

The "fauna" of the novel is rich and varied. The zoonyms, which occur there can be divided into such categories: domestic animals (goat, horse, rabbit, dog, pig, hen, cow, chicken, ram), wild animals (deer, monkey, coyote), birds (pigeon, dove, owl), insects (spider) and reptiles (snake). Acquiring a contextual meaning, they are used to emphasize a certain trait of character or their frame of mind.

The most numerous among them is the zoonym goat. The stereotypical quality related to it is obstinacy. However, in the analyzed text it acquires different contextual meanings. Firstly, it denotes cheerfulness, vigor and liveliness. In the following examples the children are described as funny, cute, energetic and full of strength young goats: " $<\ldots>$ When we ran to meet our father after his day's work he said we looked like goats, cabroncitos and cabritos" [14, p. 33]; "< ...> Deborah and Theresa passed us by like two wild goats" [14, p. 143]. In another case, this zoonym has a pejorative connotation: "The rest of the day we were like goats held by nobbles" $[14$, p. 76$]$ because on their first day at school the children do not understand anything and are at a loss. Thus, here the image of a goat implies ignorance, lack of confidence and illiteracy.

The image of horse is usually associated with a hardworking person. However, Z.R. Dubravska states that being polysemantic, this zoonym can express various meanings in different contexts [4].
In order to colourfully describe the crude appearance and unmanageable character of a street urchin, the author names him Horse. In this antonomasia (speaking name) the nominal and contextual meanings occur simultaneously: "They called him Horse because his face looked like the face of the horse, and he was always stomping at the ground" [14, p. 35]. Throughout the whole novel the writer highlights the boy's resemblance to this animal in a number of ways: "I could hear the deep sounds a horse makes inside his chest" [14, p. 37]; "His big horseeyes looked up at me nervously" [14, p. 154]; "His horse-eyes were wild" [14, p. 193]; "Horse grinned with his ugly horse teeth" [14, p. 199].

The connotation of the zoonym dog also depends on the context. It is interpreted in different modes. Z.R. Dubravska accentuates that it denotes such human qualities as cowardice and slyness [4, p. 51], whereas S.V. Talko sticks to an opposite opinion. He affirms that the dog is believed to be a symbol of friendship, loyalty, reliability, incorruptibility [12, p. 124]. In the novel by Rudolfo Anaya it is used as an insult comparing a person to the animal in terms of its worst characteristics, such as laziness or groveling [20]: "Bones snapped down at her like a concerned dog" [14, p. 152]; "Horse whinnied and reared up and Bones was on him like a mad dog" [14, p. 194]; "The others rallied to his cry and they went off howling like a pack of wild dogs" [14, p. 195].

Pig is considered to be an embodiment of negative qualities. In the example "Roque was bleeding like a pig" [14, p. 194] this lexeme is a constituent of a phraseological unit. It is used to express contempt and creates an emotive background of the situation.

In order to emphasize maternal love and care, "femininity and nurture" [22, p. 212], the boy's mother is conceptualized as a mother hen who looks after her "chicks", clinging to her in both dangerous and peaceful situations: "My mother cared for them like a mother hen cared for her chicks, even though the hawk of war has flown away" [14, p. 64].

The zoonyms cow and bull are used in different contexts. With a touch of disapproval the former describes the appearance of prostitutes whom the author euphemistically calls "sinful women": "She bowed and soft flesh of her breasts hung loose and curved like cow udders" [14, p. 70]. The latter renders the intensity of frantic and vehement movement of two brothers: “'Whoopeeeee!' They shouted. They were like wild bulls running down the goat path towards town" [14, p. 69].

According to S.V. Talko a snake's meanness is alluded to its ability to get accustomed to any conditions because it can change its skin, therefore 
a snake can be related to man's villainy [12, p. 127]. However, in the book this zoonym produces a strong stylistic effect adding to the mysticism of the episode and making it scary, as it describes the hair that witches used in divination for death: "Green bile poured from his mouth and finally he vomited a huge ball of hair. It fell to the floor, hot and streaming and wiggling like live snakes" [1, p. 103].

In the image of rabbit focus is placed on cowardice, fear and skittishness [4]. This meaning does not change in the linguistic environment: "I was so startled and frightened that I jumped like a wounded rabbit, but he made no move to catch me" [14, p. 187].

Z.R. Dubravska conceptualizes the lion as the embodiment of wisdom, power and dignity [4], and S.V. Talko considers this animal to be a symbol of bravery and courage [12, p. 122]. With a help of this zoonym the author draws attention to the character's appearance: "He wore a huge moustache and his hair flowed like lion's mane" [14, p. 126].

It is noticeable that zoonyms used in the similes describing street urchins always have negative connotation, show the boys' bad behavior, offensiveness, lack of upbringing, and acquire pejorative shade of meaning. The same is true about the image of monkey that is careless, wild and eccentric. In the following example, Bones is compared to it because of his strange outrageous behavior and manner of speaking: "Meerrrr, merrrrda, mierda! Bones cried like a monkey" [14, p. 158]. However, in the sentence "We ran up the steps past Horse and Bones who were swinging like monkeys on the bell ropes" [14, p. 198] the zoonym loses its negative meaning and emphasizes the children's state of mind presenting them as jolly, funny, playful and energetic.

The image of wolf usually symbolizes cruelty, anger and mercilessness. It is a typical character of legends and fairy tales where it performs different roles. Sometimes he acts as a powerful friend but sometimes as a pest dangerous for domestic animals [3]. In the analyzed context it is identified with a man who has done a lot of bad things to people and also indicates their disapproval of him: "He is an old wolf who drags around the ground where he has made his kill" [14, p. 189]; "Bah, do not bother your mind about that wolf' [1, p. 224].

The connotative meaning of the zoonym bear implies rudeness and impudence. Probably it is the bear's arrogance and condescension that gave rise to the meaning "an impolite impudent person" [12, p. 125]. In the context, there appears an additional meaning, which stresses the fighting men's big size and clumsiness: "They tumbled into the snow like two drunken bears" [14, p. 160].
Ascribing to the fighting men ram's features, the author emphasizes their stubbornness and persistence: "The two came together again, like two rams locking horns, and the bartender and the other two men had to pull with their strength to pry them loose" [14, p. 161]. Comparing a man with a deer the writer draws attention to his fearfulness and shyness: "Silently, like a deer, the figure of Cico emerged" [14, p. 106].

Among the positive qualities, ants represent industry, diligence, cooperation and constant movement. In the example to follow the contextual meaning of the zoonym ant coincides with its logical meaning, the focus being put on their latter peculiarity (constant movement): "The loaded wagons moved between the fields and the village like ants scurrying to store their seeds [14, p. 142]. In another episode the lexeme in question is given a little humorous shade: "Now the people gathered at its doors like ants, asking questions and passing on rumours about what happened last night" [1, p. 35].

For a special purpose, the author interprets in his own way the image of an eagle, which is known as a symbol of divine triumph [22, p. 153]. The zoonym helps to render the state of mind of the narrator, his thoughts about the past when Mexicans were deprived of their freedom: "I dreaded to think of a time when I could not walk upon the Ilano and feel like the eagle that floats in its skies: free, immortal, limitless" [14, p. 228].

According to Mark Nickol the zoonym coyote suggests a person who profits from the desperation of others and at worst cheats or misleads people or endangers their lives [20]. The following context gives evidence of the connotation mentioned above: "He landed screaming in the dust and then scrambling to his feet he ran to find refuge behind two of his coyotes" [14, p. 131].

The most significant role among all the zoonyms belongs to the $o w l$, which at the same time is a symbol permeating through the whole novel. "The predominant Western association with the owl is wisdom - as it was a symbol of the Greek goddess of Wisdom, Athena [19]. It describes one of the main characters Ultima, a wise curandera (a healer that cures with herbs and magic), who lives according to the laws of nature and knows the truth of the life on earth. Ultima implanted a part of her soul into the owl and will be alive as long as the bird lives. Therefore, the image of the owl is presented in sync with that of the old woman, is empowered with human qualities, which makes it mystic and mysterious: "Outside the owl sang its dark questioning to the night $<\ldots>$ " [14, p. 25]. Ultima and the owl blend into a single 
entity which results in resemblance in appearance: "Then she would lead me to the plant her owl-eyes had found and ask me to observe where the plant grew and how its leaves look" [1, p. 37]. In such a way the writer presents the interrelation between man and nature, their coexistence and inseparability.

\section{Conclusions.}

The present study aimed at defining the contextual meaning of zoonyms and their functions in literary text shows that animal names can be interpreted in different ways. The novel "Bless me, Ultima" by Rudolfo Anaya contains 36 cases of the use of zoonyms as components of similes; they acquire various contextual meanings. All the examples provide clear evidence that animals serve as the source domain for talking about human beings by ascribing to them certain qualities.

All the zoonyms in the novel represent domestic and wild animals and birds, insects and reptiles. They possess both positive and negative contextual meanings and are used to express various feelings and emotions.
There is the zoonym animal describing traits of character, which occurs 15 times and has a pejorative shade of meaning. In several cases it is the basis of juxtaposition man-animal. For the sake of specifying some idea and adding an emotional coloring to the situation described, it is modified by various attributes with a strong emotive meaning (wild, captured, savage, huge, turgid, frightened, starved, etc.).

A special role is played by the zoonym owl, which the author turns into a symbol accompanying the narration throughout the whole novel. It should be mentioned that the use of zoonyms contributes to better understanding of the cultural worldview of the nation and intercultural communication.

Although this paper is based on data form Rudolfo Anaya's novel, the analysis of the contextual meaning of zoonyms is applicable to texts by other authors. Moreover, the discussion of pragmatic functions of zoonyms, which is beyond the scope of the present study, can be of considerable linguistic interest.

\section{REFERENCES:}

1. Бережна М.В. Переклад зоонімів дитячої літератури жанру фентезі. Наукові записки Кіровоградського державного педагогічного університету імені Володимира Винниченка. 2009. Вип. 81 (4). С. 229-233. URL: http: //nbuv. gov. ua/ UJRN/Nzs_2009_81\%284\%29_57 (дата звернення: 02.07.2019).

2. Будагов Р.А. Человек и его язык. Москва, 1974. 264 с.

3. Головня А.В. Зоонім як складник порівняння на позначення рис характеру людини (про вибір засобів україномовного перекладу порівнянь з компонентом-зоонімом у прозі Редьярда Кіплінга). Всесвітня література в середніх навчальних закладах України. 2011. № 6. С. 67-76.

4. Дубравська 3.P. Зооніми як окремі лексичні одиниці та як компоненти сталих виразів. Young Scientist. № 3.1 (55.1). 2018. URL: http://molodyvcheny. in.ua/ files/ journal/2018/3.1/13.pdf (дата звернення: 02.07.2019).

5. Кечкеш И. Слово, контекст и коммуникативное значение. Лингвопрагматика и межкультурная коммуникация. Вестник РУДН. Серия «Лингвистика». 2014. № 1. С. 7-18. URL: https://cyberleninka.ru/article/n/ slovo-kontekst-i-kommunikativnoe-znachenie (дата звернення: 02.07.2019).

6. Коваленко О.В., Рзаєва В.В. Функціонування зоосемізмів у фразеологізмах німецької та української мов. Одеський лінгвістичний вісник. 2013. Вип. 2. C. 30-38. URL: https://core.ac.uk/download/pdf/50595273. pdf (дата звернення: 02.07.2019).

7. Панченко О.І. Фразеологізми з компонентом-зоонімом в українській та англійській мовах. Ученые записки Таврического национального университета им. В.И. Вернадского. Серия “Филология. Социальные коммуникации". 2014. Том 27 (66). № 1. Ч. 1. С. 111-114.

8. Переверзева Н.А. О разных подходах изучения контекста. Вестник Вятского государственного универсumema. 2017. C. 52-56. URL: https:// cyberleninka.ru/article/v/o-raznyh-podhodah-k-izucheniyu-konteksta-vlingvistike (дата звернення: 02.07.2019).

9. Петришин М.Й. Фразеологізми з компонентом-зоонімом у латинській мові. Науковий вісник Чернівецького університету. Германська фрілологія. 2014. Вип. 692-693. C. 161-165. URL: http://nbuv.gov.ua/ UJRN/Nvchnugf_2014_692-693_49 (дата звернення: 02.07.2019).

10. Покровська І.Л. Національна специфіка семантики турецьких фрразеологізмів з компонентом-зоонімом : автореф. дис. ... канд. філол. наук : 10.02.13. Київ, 2007. 20 с.

11. Рахнянський В.В. Образ осені в романі Р. Анайї «Осінь на Ріо-Гранде». Наукові праці. 2006. Том 59. Випуск 46. C. 73-75. URL: http://lib.chdu. edu.ua/ pdf/ naukpraci /philology/2006/59-46-28.pdf (дата звернення: 30.06.2019).

12. Талько С.В. Лінгвоаксіологічна семантика антропоцентричних метафор та порівнянь у лексико-семантичному просторі зоонімів в українській і англійській мовах. Вісник КНЛУ. Серія Філологія. 2016. Том 19. № 1. С. 121-132.

13. Шевчик А.В. Образные зоонимы русского и английского языков: общность и специфика. Филология. 2010. C. 30-33. URL: https:// cyberleninka.ru/article/v/obraznye-zoonimy-russkogo-i-angliyskogo-yazykovobschnost-i-spetsifika (дата звернення: 04.07.2019). 
14. Anaya R.A. Bless me, Ultima : New York : Warner Books, 1972. 262 p.

15. Dash N.S., Ray A. Investigating the Nature of Use of Animal Names in Bengali Written Texts. Lanuage Forum. 2014. Vol. 40. N 1-2. URL: (Last accessed: 29 June 2019).

16. Finzel Anna. Multimodal metaphors in films: People are animals. Language in Use: Metaphors in Non-Literary Contexts. 2016. URL: (Last accessed: 4 July 2019).

17. Halupka-Rešetar Sabina, Radic Biljana. Animal names used in addressing people in Serbian. Journal of Pragmatics. 2003. Vol. P. 1891-1902. URL: (Last accessed: 29 June 2019).

18. Kulchytska, O.O. Baloh, E.A. Seymor Glass: Contextual and linguistic identity. Journal of Vasyl Stefanyk Precarpathian National University. Series of social and human sciences. 2015. Vol. 2, No. 2-3. P. 77-86.

19. McCarthy Kevin. What is the negative connotation for the word 'owl'? URL: https://www.quora.com/What-isthe-negative-connotation-for-the-word-owl-1 (Last accessed: 29 June 2019).

20. Nickol Mark. Animals that inspire canine connotations. URL: https://www.dailywritingtips.com/5-animals-thatinspire-canine-connotations/ (Last accessed: 4 July 2019).

21. Parihar Uma. The world beyond the words: an axiological comparative study of zoonysms of Russian and Hindi. Вестник РУДН. Серия Лингвистика. 2015. № 3. С. 54-72. URL: https://cyberleninka.ru/article/v/the-worldbeyond-the-words-an-axiological-comparative-study-of-zoonyms-of-russian-and-hindi (Last accessed: 4 July 2019 ).

22. Werness B. Hope. The Continuum encyclopedia of animal symbolism in art. London. 2017. URL: https://www.worldcat.org/title/continuum-encyclopedia-of-animal-symbolism-in-art/oclc/1016327662 (Last accessed: 4 July 2019).

УДК 81'373.7:811.111

DOI https://doi.org/10.32782/tps2663-4880/2019.10.21

\title{
СТРУКТУРНО-СЕМАНТИЧНІ ОСОБЛИВОСТІ ІДІОМ-НОМІНАЦІЙ ЛЮДИНИ ЗА ÏÏ ХАРАКТЕРОМ
}

\author{
STRUCTURAL AND SEMANTIC ASPECTS OF IDIOMS NOMINATING \\ HUMAN PERSONALITY
}

\author{
Павленко Н.О. \\ orcid.org/0000-0002-7117-1179 \\ кандидат філологічних наук, \\ старший викладач кафедри англійської мови \\ Київського університету імені Бориса Грінченка
}

\begin{abstract}
У статті розглянуто структурні та семантичні аспекти ґендерно маркованих фрразеологізмів, що номінують людину за рисами характеру. Звернення до аналізу ґендерно маркованих фразеологізмів дає змогу дослідити соціокультурні параметри англомовного суспільства і з'ясувати тенденції, зумовлені розподілом статевих ролей. Адже фразеологія $€$ втіленням суспільних явищ і трендів, які можуть змінюватися в процесі еволюції суспільства, але залишатися назавжди закарбованими в мовній системі. Добір емпіричного матеріалу було здійснено завдяки структурному та семантичному критеріям, тобто за наявності ґендерного маркеру в структурі або значенні фрразеологічної одиниці. Запропоновано методику виокремлення ґендерно маркованих одиниць на позначення характеру людини із фразеологічного фонду англійської мови. Фразеологізми на позначення людини за рисами характеру мають різноманітне походження. Завдяки етимологічному аналізу було встановлено такі джерела походження досліджуваних одиниць, як: історичні події, літературні та шекспірівські твори, театральний вокабуляр, Біблія та іншомовні ресурси. Структурний аналіз засвідчив, що серед ідіом-позначень людини за рисами характеру переважають субстантивні, ад'єктивні та звороти зі структурою речення. Було встановлено низку фразеологічних номінацій, завдяки яким було сфрормовано досліджувані одиниці. Комплексний структурно-семантичний аналіз ґендерно маркованих фрразеологізмів англійської мови дає змогу докладно представити чоловіка й жінку та їхні традиційно сфрормовані й набуті з часом фуннції в сучасному суспільстві, а також розкрити та детально описати отримані дані щодо сталих стереотипів і уявлень стосовно розподілу ґендерних ролей.
\end{abstract}

Ключові слова: ідіома, ґендерний компонент, етимологія, конотація, семантика, структура, фрразеологічна номінація.

This paper focuses on the research of structural and semantic peculiarities of gender idioms denoting human personality, which means that the aim of this research is to discover and reveal the mechanisms of gender specificity in the structure and meaning of phraseological units nominating women's and men's features of character. Referring to the socially constructed characteristics of men and women, such as norms, roles and relationships and between groups of women and men, gender is represented in the language model of the world by different language means, idioms among them. 